(науковий керівник - доктор біологічних наук, професор Н. О. Волочина)

Національний педагогічний університет ім. М. П. Драгоманова

\title{
ОЦІНКА ЗАЛЕЖНОСТІ УРОЖАЙНОСТІ ОЗИМОЇ ПШЕНИЦІ ВІД ВПЛИВУ МЕТЕОРОЛОГІЧНИХ ФАКТОРІВ В УМОВАХ ЗОНИ ЛІСОСТЕПУ
}

\section{Рецензент - кандидат біологічних наук В. М. Лавріненко}

У статті на прикладі типових аграрних підприємств зони Лісостепу здійснено комплексний аналіз кліматичних факторів і продуктивності агроекосистем. У результаті досліджень встановлено кореляційну залежність урожайності озимої пшениці від окремих кліматичних чинників за 20-річний період (1997-2016 рр.). За визначеними математичними моделями були побудовані графіки функиій, які дають змогу прогнозувати рівень урожайності культури за різного впливу кліматичних факторів. Установлено, щуо для пшениці озимої найвагомімими метеорологічними факторами є кількість опадів травня $і$ червня, а також запаси продуктивної вологи в 20 см шарі грунту у квітні та травні.

Ключові слова: кліматичні фактори, урожайність, озима пшениця, кореляційно-регресійний аналіз.

Постановка проблеми. Серед комплексних груп факторів, кліматичні займають особливе місце, оскільки безпосереднім чином визначають всі процеси в екосистемі, умови та межі життя організмів, їх поширення, активність, відтворення. Для кліматичних умов Лісостепової зони характерними є порівняно м'яка зима, помірно вологе й тепле літо, що є досить сприятливим для одержання високих i сталих урожаїв озимих культур [6, 7].

Температура навколишнього середовища впливає на всі процеси життєдіяльності сільськогосподарських культур: інтенсивність фотосинтезу й дихання, поглинання води й мінеральних речовин, транспірацію, i, відповідно, позначається на особливостях формування врожаю. У свою чергу, атмосферні опади виступають важливим кліматичним ресурсом, завдяки якому утворюються запаси води в грунті, що впливають на ріст рослин. Саме тому запаси грунтової вологи, які можуть використовуватись рослиною впродовж вегетаційного періоду (продуктивна волога) є важливим показником і фактором підвищення урожайності [1, 2]. Оскільки, озима пшениця, навіть за достатнього забезпечення поживними речовинами і дотримання агротехні- чних вимог іiі вирощування, дуже вибаглива до запасів грунтової вологи. Це пов'язано із тим, що строки сівби озимої пшениці співпадають із найбільш сухим періодом року. Запаси вологи в грунті визначають своєчасність появи сходів, розвиток рослин, що й впливає головним чином на рівень майбутнього врожаю [4].

Аналіз останніх досліджень і публікацій, у яких започатковано розв'язання проблеми. Дослідження впливу кліматичних факторів на урожайність культур розглянуто В. Л. Дмитренком [2], Л. М. Попитченком [4], Ю. О. Тараріко [1] та іншими. Зокрема, вченими відзначається, що в Україні в останні роки проводяться роботи по оцінці реакції зернових культур на зміну клімату та умов вирощування сільськогосподарських культур [4]. Водночас достовірним $є$ той факт, що для забезпечення стабільного розвитку сільськогосподарського виробництва, визначальним фактором виступає можливість прогнозування продуктивності окремих культур. Оптимум значення кліматичних параметрів коливається в широких межах для схожих грунтовокліматичних умов. Питання залежності біологічної продуктивності агроекосистеми від комплексного впливу метеорологічних чинників наразі $€$ досить актуальним та потребує додаткового вивчення.

Мета дослідження полягає у виявленні залежності урожайності озимої пшениці від впливу метеорологічних факторів в умовах зони Лісостепу.

Головним завданням виступає встановлення кореляційної взаємозалежності урожайності озимої пшениці від впливу середньої місячної температури повітря, кількості опадів, а також запасів продуктивної вологи грунту.

Матеріали та методи дослідження. Було досліджено залежність показників урожайності пшениці озимої від таких метеорологічних параметрів, як середньомісячні показники температури повітря, кількості опадів та запасів продуктивної вологи грунту за допомогою кореляційно-регресійного аналізу. Дані по врожайності 
сільськогосподарських культур зібрані за матеріалами облікових щорічних звітів у Райдержадміністрації міста Лубни. Спостережні ділянки знаходилися на базі дослідного сільськогосподарського господарства Лубенської метеорологічної станції СФГ «Роксолана» (сівозміна восьмипільна, повторюваність чотириразова). Метеорологічні дані були отримані із архівів Лубенської метеорологічної станції (найближчій до господарств) за період з 1997 по 2016 роки.

Результати досліджень. Для визначення залежності продуктивності зернових культур від погодних умов було розглянуто статистичні ряди $з$ урожайності пшениці озимої Лубенського району Полтавської області за період з 1997 по 2016 роки (рис. 1); річної, середньомісячної кількості опадів, температури, а також запасів продуктивної вологи впродовж даного періоду.

За період аналізу зміни урожайності озимої пшениці було відмічено, що їі показники коливалися в межах від 0,8 т/га до 4,9 т/га. Для виявлення закономірності даної зміни було прораховано значення коефіцієнта кореляції для урожайності озимої пшениці метеорологічних параметрів за 20-річний період. Водночас встановлено, що опади мають більш вагомий вплив на продуктивність зернових, ніж температура. Для досліджуваної культури - це кількість опадів травня і червня.

Про наявність прямого кореляційного зв'язку свідчить значення коефіцієнта кореляції - 0,8. Параметри рівнянь окремих функцій математичної моделі по даному фактору наведені в таблиці 1.

Дані потреби у волозі, насамперед, пов'язані із нерівномірністю іiі поглинання озимою пшеницею впродовж періоду вегетації [3]. Найбільша іiі необхідність пов'язана із фазою трубкування, коли рослина перебуває у стані інтенсивного росту (формування квіток та колосків) і періодом від колосіння до повної стиглості зерна (травень - червень). Нестача вологи в цей час $\epsilon$ вкрай несприятливою для культури та призводить до зниження врожаю. Зокрема, наявність прямого кореляційного зв'язку вказує на те, що кількість опадів травня та червня є найбільш вагомим фактором впливу на урожайність пшениці озимої.

За визначеними математичними моделями кореляційної залежності врожайності культури від метеорологічних показників були побудовані графіки функцій (рис. 2).

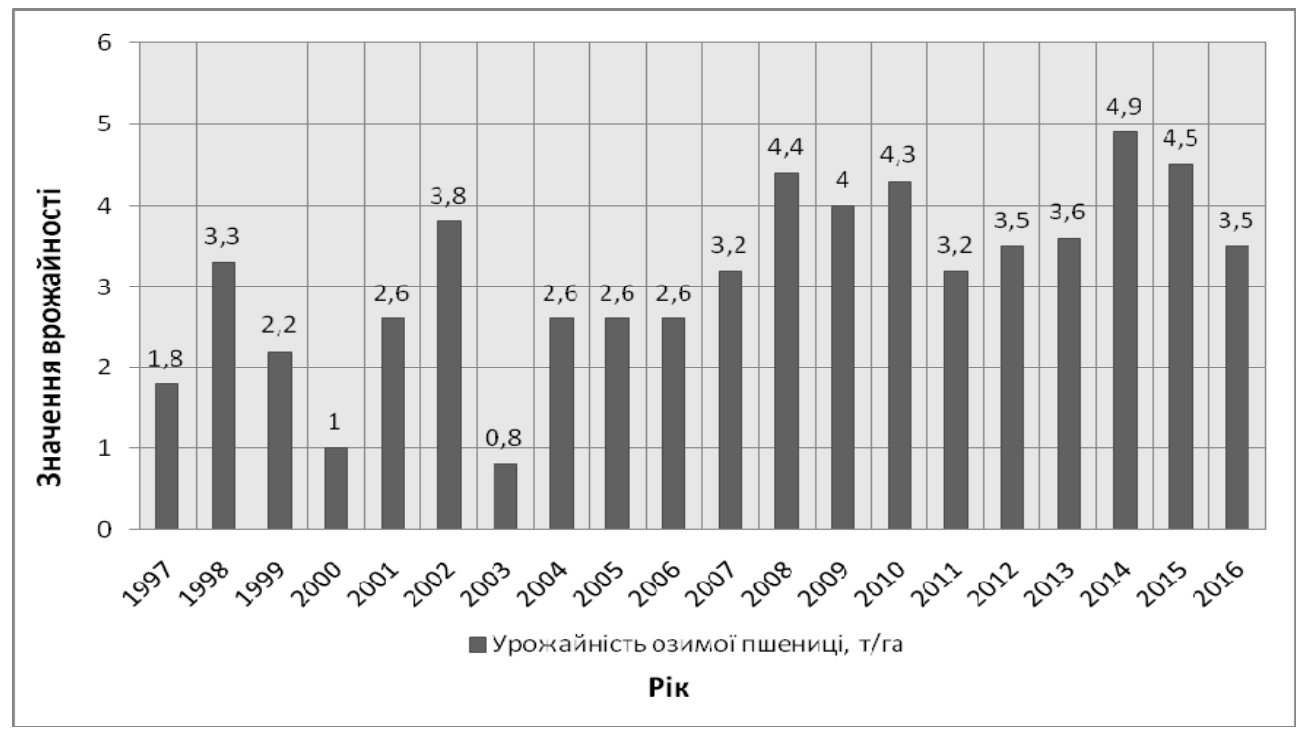

Рис. 1. Урожайність озимої пшениці за період 1997-2016 рр.

\section{1. Математико-статистична модель урожайності пшениці озимої} залежно від кількості опадів

\begin{tabular}{|c|c|c|}
\hline Фактор & $\begin{array}{c}\text { Рівняння парної } \\
\text { регресії }\end{array}$ & $\begin{array}{c}\text { Коефіцієнт парної } \\
\text { кореляції }\end{array}$ \\
\hline Кількість опадів травня & $\mathrm{y}=0,02 \mathrm{x}+1,89$ & 0,8 \\
\hline Кількість опадів червня & $\mathrm{y}=0,03 \mathrm{x}+0,88$ & 0,8 \\
\hline
\end{tabular}


Згідно $з$ графіком (рис. 2) прослідковується пряма кореляційна залежність між збільшенням урожайності пшениці озимої відповідно до зростання кількості опадів травня. Максимальне значення показника урожайності травня та червня $(3,89$ т/га та 4,18 т/га) прогнозується в разі кількості опадів 100 мм та 110 мм відповідно.

Аналізуючи вибірку даних по врожайності пшениці озимої в Лубенському районі та власні дослідження за 2016-й рік, визначено, що кількість опадів вище середнього значення по кліматичній зоні Лісостепу за роки дослідження (53 мм) забезпечує підвищення даного показника. Відносно високий урожай $(3,8$ т/га) був фіксований у 2002 р., коли кількість опадів травня, червня відповідала 58,7 мм та 78,0 мм; 4,4 т/га у 2008 p. за 57,5 мм і 78,6 мм; а також у 2014 р. 4,9 т/га за 66,1 і 76,2 мм опадів.

Однією із визначальних умов отримання високого урожаю сільськогосподарських культур $\epsilon$ ступінь забезпечення продуктивною вологою, яка засвоюється внаслідок грунтового живлення [5]. Саме тому даний параметр (запаси продуктивної вологи) виступає важливим фактором підвищення урожайності культур.

Упродовж періоду від посіву до фази кущіння стан зернових визначається вологістю верхнього шару грунту (0-20 см). Для аналітичного обгрунтування характеру впливу визначеного чинника на процес вегетації озимої пшениці були застосовані методи математичної статистики. У результаті досліджень встановлено наявність прямої кореляційної залежності урожайності пшениці озимої від запасів продуктивної вологи в 20-ти сантиметровому шарі грунту в окремі місяці за 20-ти річний період. Водночас найбільший вплив на урожайність мають квітневі та травневі запаси продуктивної вологи, про що свідчить значення коефіцієнта кореляції - 0,8 i 0,9 відповідно.

Параметри рівнянь функцій математичної моделі по факторах, які впливають на урожайність пшениці озимої, наведені в таблиці 2.

Дана закономірність пов'язана із біологічними потребами найбільшої чутливості озимої пшениці в період від початку весняної вегетації до колосіння. В разі оптимального вологозабезпечення рослин, насамперед у період від виходу в трубку до колосіння, є вірогідність отримання високого урожаю.

За визначеними математичними моделями кореляційної залежності урожайності культури від запасів продуктивної вологи було побудовано графіки функцій (рис. 3).

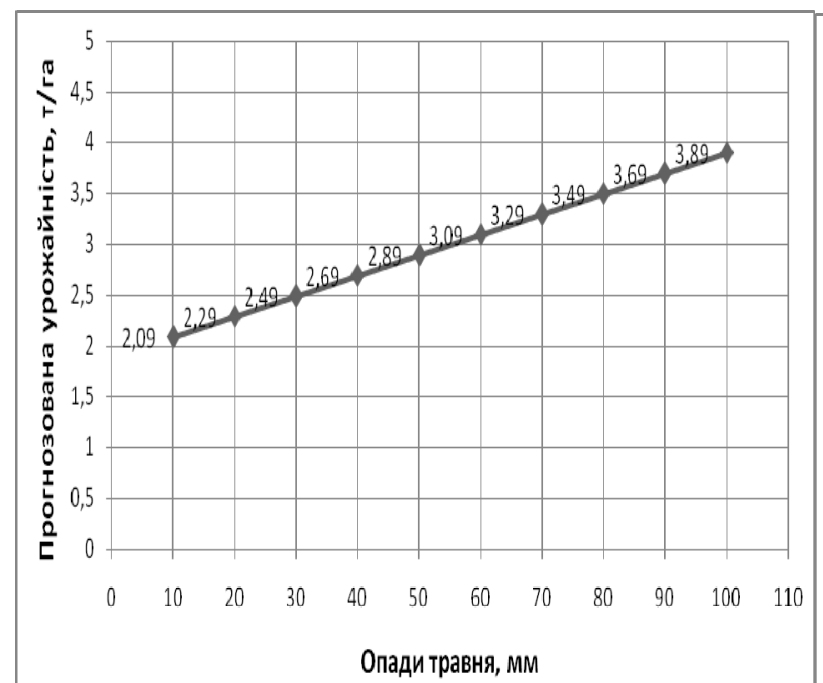

A

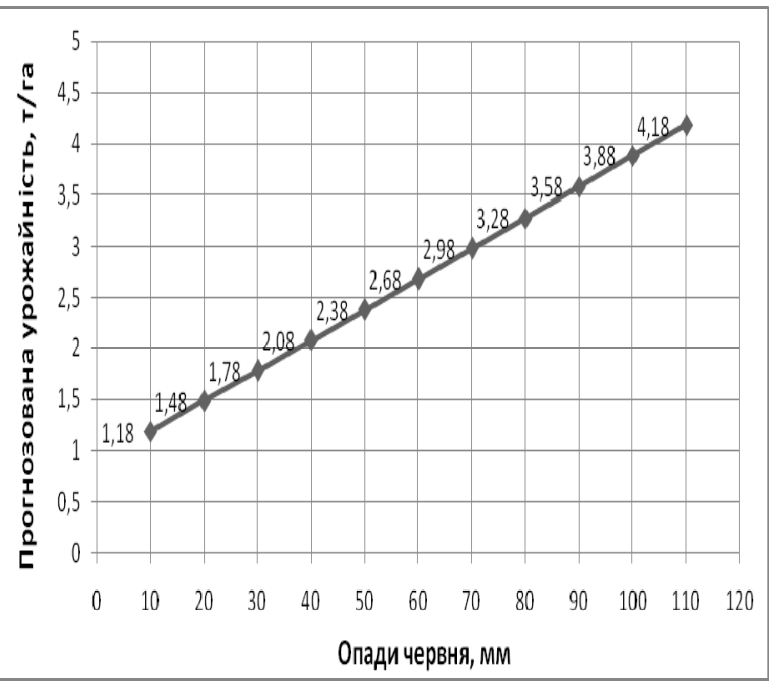

Б

Рис. 2. Функціональна залежність урожайності пшениці озимої від кількості опадів травня (А) та червня (Б)

2. Математико-статистична модель урожайності пшениці озимої

\begin{tabular}{|l|c|c|}
\hline \multicolumn{1}{|c|}{ Фактор } & Рівняння парної регресії & Коефіцієнт парної кореляції \\
\hline $\begin{array}{l}\text { Запаси продуктивної вологи } \\
\text { квітня }\end{array}$ & $\mathrm{y}=0,15 \mathrm{x}-1,73$ & 0,8 \\
\hline $\begin{array}{l}\text { Запаси продуктивної вологи } \\
\text { травня }\end{array}$ & $\mathrm{y}=0,21 \mathrm{x}-1,73$ & 0,9 \\
\hline
\end{tabular}



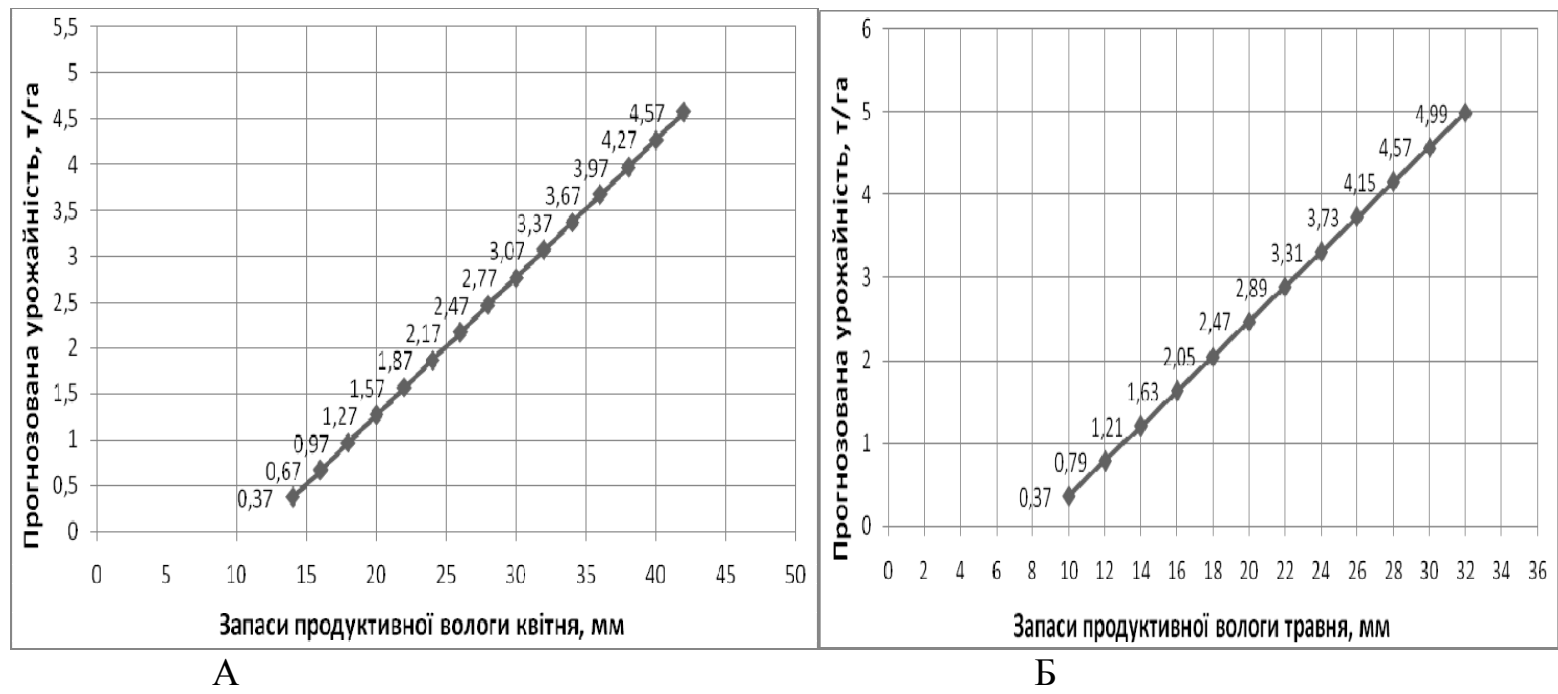

\section{Рис. 3. Графіки функціональної залежності урожайності пщениці озимої від запасів продуктивної вологи квітня (А), травня (Б)}

Згідно із графіком (рис. 3), збільшення запасів продуктивної вологи квітня та травня відображається на зростанні показника урожайності пшениці озимої. Ї̈̈ максимальні значення (близько 4,57 т/га) відповідно прогнозуються в разі запасів 42 мм у квітні та близько 5 т/га у випадку 32 мм у травні.

Висновок. Під час комплексного аналізу залежності продуктивності агроекосистеми від впливу кліматичних факторів було встановлено, що на урожайність пшениці озимої передусім впливає кількість опадів травня та червня (прослідковується тісний кореляційний зв'язок за якого коефіцієнт кореляції становить 0,8 ), а також запаси продуктивної вологи квітня та травня

\section{БІБЛІОГРАФІЯ}

1. Вплив агротехнологічних і агрометеорологічних факторів на продуктивність агроекосистем / [Тараріко Ю. О., Чернокозинський А. В., Сайдак Р. В., Глущенко Л.Д., Величко В. А., Срьоміна Т. А.] // Вісн. аграр. науки. - 2008. №5. - C. 64-67.

2. Дмитренко В. П. Погода, клімат і урожай польових культур : [монографія] / В. П. Дмитренко // НАН України, Укр. наук.дослід. гідрометеоролог. ін-т. - К. : Ніка-Центр, 2010. $-620 \mathrm{c}$.

3. Зінченко О. I. Рослинництво : [підручник] / О. І. Зінченко, В. Н. Салатенко, М. А. Білоножко. - К. : Аграрна освіта, 2001. - 591 с.

4. Попитченко Л. М. Погодно-кліматичні умови вегетації озимої пшениці в Луганській області (коефіцієнт кореляції 0,8 і 0,9 відповідно). За побудованими математико-статистичними моделями, розрахунковий максимум урожайності пшениці у травні та червні (4 т/га та 4,24 т/га) прогнозується за кількості опадів 100 мм та 110 мм відповідно. Тоді як у випадку запасів продуктивної вологи у квітні (44 мм) і травні (32 мм) прогнозований максимум урожайності становить близько 4,6 т/га та 5 т/га відповідно. Розраховані рівняння дають змогу визначити продуктивність агроекосистеми відповідно до конкретного метеорологічного параметру, що, у свою чергу, дає змогу прогнозувати рівень урожайності культури за різного впливу кліматичних факторів.

/ Л. М. Попитченко // Збірник наукових праць Луганського національного аграрного університету. Серія «Сільськогосподарські науки». - Луганськ : «Елтон-2», 2009. - №100. - С. 121-124.

5. Фурдичко O. I. Агроекологія : [монографія] / O. I. Фурдичко // Нац. акад. аграр. наук України, Ін-т агроекології і природокористування. - К. : Аграрна наука, 2014. - 399 с.

6. Lonsdale $K$. G. (Eds). Climate Change. Climate, Variability and Agriculture in Europe. Environmental Change Unit / K. G. Lonsdale. University of Oxford, UK. - 2008. - P. 367-390.

7. Parmesan C. Ecological and evolutionary responses to recent climate change / C. Parmesan // Annual Rev. Ecol. Evol. Sys. - 2006. - P. 37. 